\title{
The Potential Importance of Maize, (Zea Mays L), in Nigeria, [A Case Study of 2,800 Farmers Sampled at Different Locations]
}

\author{
Prince Awojoodu Soji \\ Department of Computer Science and Mathematics, Oduduwa University, Ile-Ife Kingdom, Nigeria
}

\section{Email address:}

awojoodusoji@yahoo.com

\section{To cite this article:}

Prince Awojoodu Soji. The Potential Importance of Maize, (Zea Mays L), in Nigeria, [A Case Study of 2,800 Farmers Sampled at Different Locations]. Advances in Biochemistry. Vol. 8, No. 1, 2020, pp. 1-10. doi: 10.11648/j.ab.20200801.11

Received: August 17, 2019; Accepted: September 9, 2019; Published: January 6, 2020

\begin{abstract}
This research work was carried out, to find the potential importance of maize, in Nigeria.4 Local governments, namely: (Ife East, Ife South, Ife Central and Ife North), local government areas, in Nigeria were sampled. 2,800 open questionnaires were distributed to 4 Local Governments, out of which 700 was used for farmers in each local government. A total of 28 different locations, was visited in all the four Local Governments, out of which100 questionnaires were used in each location. It was gathered that above $80 \%$ of the farmers from the four local governments, supported, the potential importance of maize, in Nigeria, while below $20 \%$ of the farmers, could not even understand, whether there was any need for the potential importance of maize, in Nigeria, or not. The results from the questionnaires when using Pearson two-tailed correlation coefficient, however revealed that there was a significant difference from all the farmers visited and sampled, $(\mathrm{p}>0.01)$ and $(p>0.05)$ respectively, table 5. This shows a strong positive correlation, which implying that, the potential importance of maize, in Nigeria, is strongly influenced and enhanced the farmers and support, and, had therefore, made this research work to become a reality, $(p>0.01)$ and $(p>0.05)$, table 5. The reasons may be due to the fact that, Maize (Zea Mays L), is not only served as the most productive grain crops in the middle and northern belts of Nigeria where sunshine is adaptable and rainfall is moderate; It however serves as a basic raw materials to thousands of industrial products that may includes: alcoholic, beverages, pharmaceutical, food sweeteners, food cereals, cosmetic and films, gums, package, textile, paper industries and so on. And also, as one of African's dominant food crop, maize can be consumed in varied forms, such as: maize flour for confectionaries, semo (for swallow with soup), as corn beef, mill (for animals feeding), as roaster corn, it can be boiled or prepared as porridge. Bar chart was used to depict the summary data of each of the local government areas sampled in Ile-Ife Kingdom, of Nigeria.
\end{abstract}

Keywords: Maize (Zea Mays L), Corn, Harvest, Storage, 4 Local Governments, Osun State, Pearson Correlation

\section{Introduction}

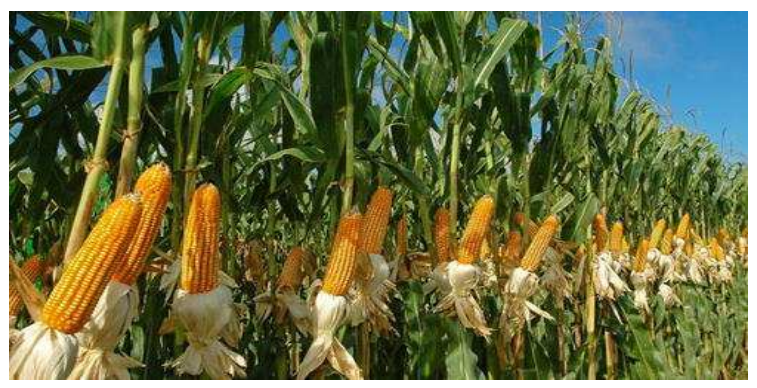

Figure 1. Maize (Zea Mays L), as the cereal of the future.
Maize (Zea Mays L), commonly known as corn in the United States and Canada, is the most important cereal grain Worldwide after wheat and rice, [1]. It is also referred to as the cereal of the future, for its nutritional value and utilization of its products, [2].

It is the most productive grain crops in the middle and northern belts of Nigeria where sunshine is adaptable and rainfall is moderate. It is one of the oldest human cultivated crops. It had a tremendous variability in kernel color, textile, composition and appearance. It serves as a basic raw materials to thousands of industrial products that may includes: alcoholic, beverages, pharmaceutical, foods 
sweeteners, food cereals, cosmetic and films, gums, package, textile, paper industries and so on. As one of African's dominant food crops, maize can be consumed in varied forms, such as: maize flour for confectionaries, semo (for swallow with soup), as corn beef, mill (for animals feeding), as roaster corn, it can be boiled or prepared as porridge. It is the most versatile emerging cash crops, having wider adaptability under varied climatic conditions and called the queen of cereals globally. In all parts of Africa, green (fresh) maize is boiled or roasted in its cob and served as snacks. Maize is often consumed as vegetable. In Nigeria, more than $60 \%$ of maize production is also consumed by industrial sector for the production of beer, malt drinks, maize flakes, starch, syrup, dextrose, and animal feed, because there is so much value in the industrial processing of maize, especially into animal feed. The crop is richer in vitamins $\mathrm{A}$, and $\mathrm{E}$, carbohydrates, essential minerals, and contain $9 \%$ protein. They are also rich in dietary D and calories which are a good source of energy, [3]. Maize or grain grows well in rich loamy or sandy loamy soil. Such soil has to be well drained area and suitable on a fairly flat landscape. It grows relatively well in a wider range of soil type than rice. Almost every part of Nigeria can grow maize in their soil. Since sunlight is very necessary and prosper to maize, Nigeria is a country blessed with abundant sunlight, therefore, maize can grow successfully in almost every state of the country.

\subsection{Origin}

The centre of its origin was believed to be traced to Mesoamerica region, as far back as 7000 years past, when it was grown as a wild grass called teosinte in the Mexican highlands, [4]. Botanically, maize (Zea Mays L) belongs to the grass family grammeaneae (Poaceae). It is an annual plant with an extensive fibrous root system. And it is a diploid species with a chromosome number of $2 n=2 x=20[5]$.

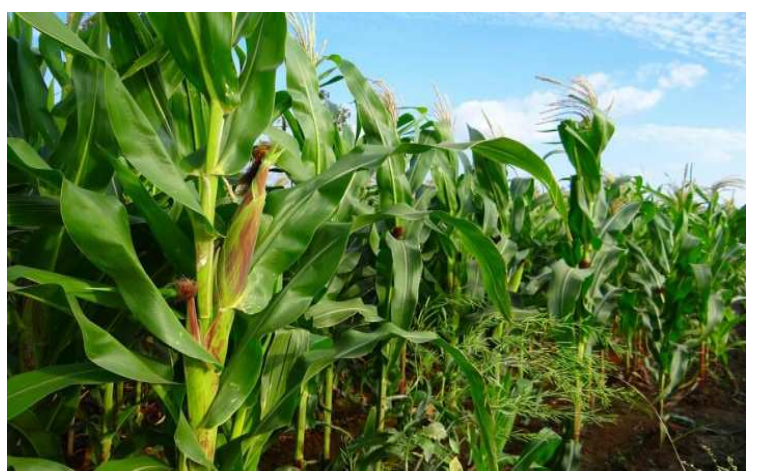

Figure 2. Maize (Zea Mays L), months and periods of maturity in Nigeria.

\subsection{Months and Periods of Maturity of Maize (Zea Mays L) in Nigeria}

Maize matures very fast. Between 3-4 months after planting, this crop will be ready for harvest. In the Southern Nigeria, early maize is sown by March/April, for early maturing seed variety and by July/August for late maturing seed variety; while in the Northern Nigeria, early maize is sown by
May/June. Harvesting of early maize is done by May and Late Maize is harvested by October. After three or four months of tending the maize plant, the farmers is ready to harvest.

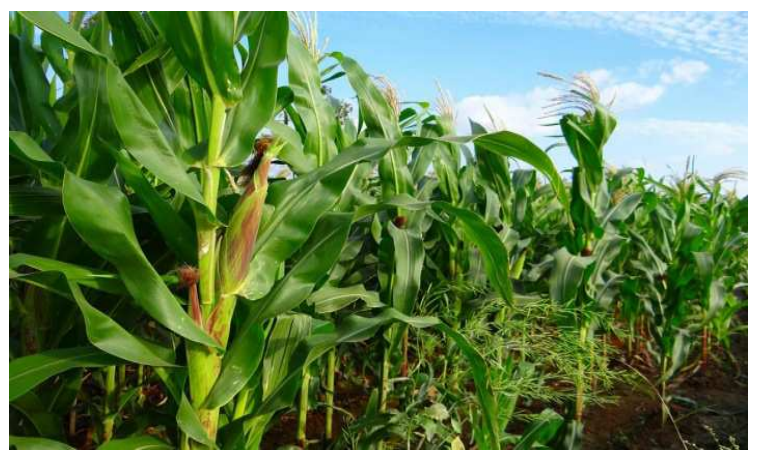

Figure 3. Maize (Zea Mays L), spoilage before harvest and storage.

\subsection{Maize (Zea Mays L) Spoilage Before Harvest and Storage}

In order to maintain high quality of maize for both short term and long term harvest and storage, maize should be protected from weather (including relative humidity and temperature), growth of microorganisms and insects, [6]. Fungal growth in maize is facilitated by hot and humid conditions, [7]. Drought, humidity, temperature, insects, infestation, and rough handling have been suggested as factors which contributed to the presence of fungi and subsequently toxins in agricultural products, [8].

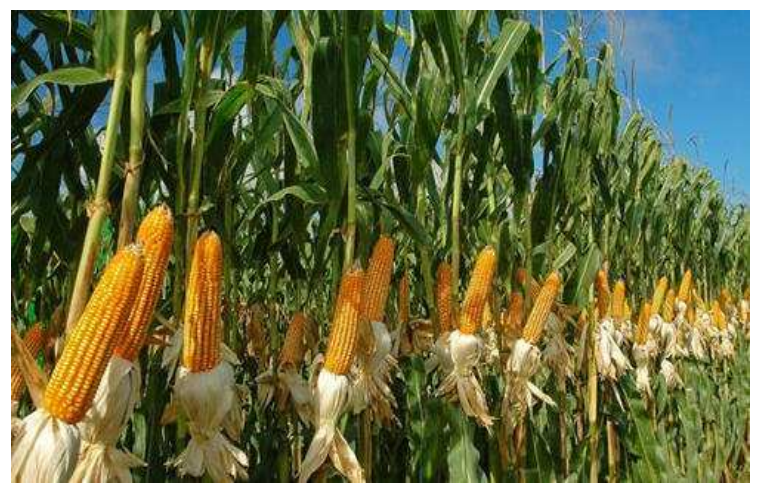

Figure 4. Maize (ZeamaysL), although, commercially lucrative, some risks are connected in growing it and should be well understood, because, maize is extremely sensitive to droughts, insects and pests.

Although, maize is commercially lucrative, there are some risks connected in growing it. This is because, maize is extremely sensitive to droughts, insects and pests. In Nigeria and other African countries, these may lead to crop's failure and can resulted to famine, in some cases. Insect pests can seriously reduce plant implantation, plant population, plant growth and subsequent yield potential, and must be monitored prior to planting. Seed treatments helps deter food. Watering in dry weather prevents the hulls from loosening. Diseases and insects in maize farming like (Downy, mildew and leaf spot), if the affected plants is not removed, and sprayed with (mancozeb, $1 \mathrm{~kg}$ per hectare of land), 20 days after sowing, usually causes the maize to dry and die. Black earwigs is a 
sporadic and potentially important pest of maize. Black earwigs eat newly sealed seed and the roots of crops resulting in a poor establishment. Birds are always problems to maize. They eat newly sealed seeds and destroy the entire root. Design a rough cloth on dry trees, like a stature of human being in all conspicuous areas inside the farm. (as wind blows, since they are birds, they ran away and never turn back). True wireworm larvae: causes damaged to the root or body of the seedlings. Then, crop growth will be delayed, by dying. False wireworm larvae: attacked the seed during the process of formation, including the shoots of young plants in the spring, resulting in uneven stands. Spray with (mancozeb, $1 \mathrm{~kg}$ per hectare of land), 20 days after sowing.

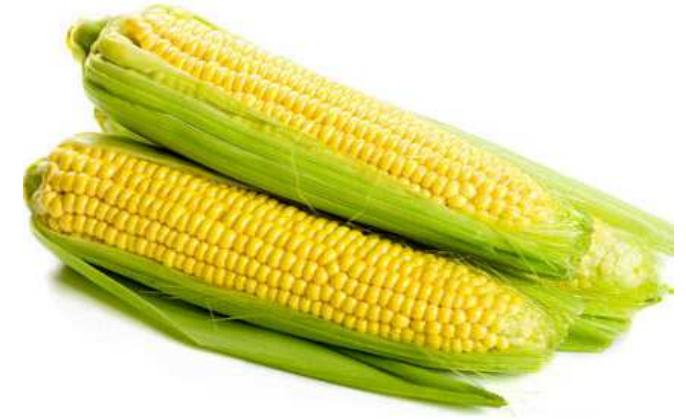

Figure 5. Maize (Zea Mays L), if harvested, need be stored under hot and humid conditions, most farmers lack proper knowledge, and equipment methods of drying grains. Exposure to moist and humid conditions during storage will cause the kennel to absorb water from the surroundings, [9].

In tropical and sub tropical countries, a large proportion of the grain, (such as maize) is harvested and stored under hot and humid conditions, and most farmers lack proper knowledge, equipment methods of drying grains, [10]. Subsequently, the maize is stored while still relatively moist and warmth and high moisture contents can result in rapid deterioration of the grain and promote the growth of microorganisms (e.g. fungi and bacteria), and insects in the grains, [1]. Maize, like other stored products is hygroscopic in nature and tends to absorb or release moisture. Even if properly dried, after harvest, exposure to moist and humid conditions during storage will cause the kennel to absorb water from the surroundings, [13]. Leading to increase in maize moisture content, which resulted in enhanced deterioration. The current estimates of the cost of grain loss due to insect and microorganisms, damage of grain stored in developing countries each year ranged from $\$ 500$ million to $\$ 1$ billion, [14]. Also reported that insects in grain enhanced mould development. Because they increase moisture content and temperature, and open areas of the grain for attack. Fungal growth in maize is facilitated by hot and humid conditions, [15].

\section{Study Area}

The study has been conducted in Nigeria. It is located in the West of Africa on the Gulf of guinea and has a total of $923,768 \mathrm{~km}^{2}$ (356.669 square mile), making it the world's $32^{\text {nd }}$-largest country (after Tanzania). It is comparable in size to Venezuela, and is about twice the size of California. It shares a 4.047 kilometers (2.515 square mile), border with Benin (773 km.), Niger (1497 km.), Chad (87 km.), Cameroon $(1690 \mathrm{~km}$.), and has a coastline of at least $853 \mathrm{~km}$. [51]. Nigeria lies between latitude $4^{\circ}$ and $14^{\circ} \mathrm{N}$, and longitude $2^{\circ}$ and $15^{\circ} \mathrm{E}$ (Encyclopedia Britannica). Nigeria is a densely populated country with the highest density of 477.0 /square mile. As at a (2012) estimate, the country held a population of more than 168.8 million people up from the 140 million recorded in her (2006) population census (World Bank Nigeria Data (2012)). Of this population, about 87 million people $(52 \%)$ dwell in rural areas while 81 million dwell in urban areas (Trading Economics Rural Population Chart (2012)). The Male/Female ratio is $1: 05$, where male commands $51.21 \%$, while females, $48.79 \%$, [16].

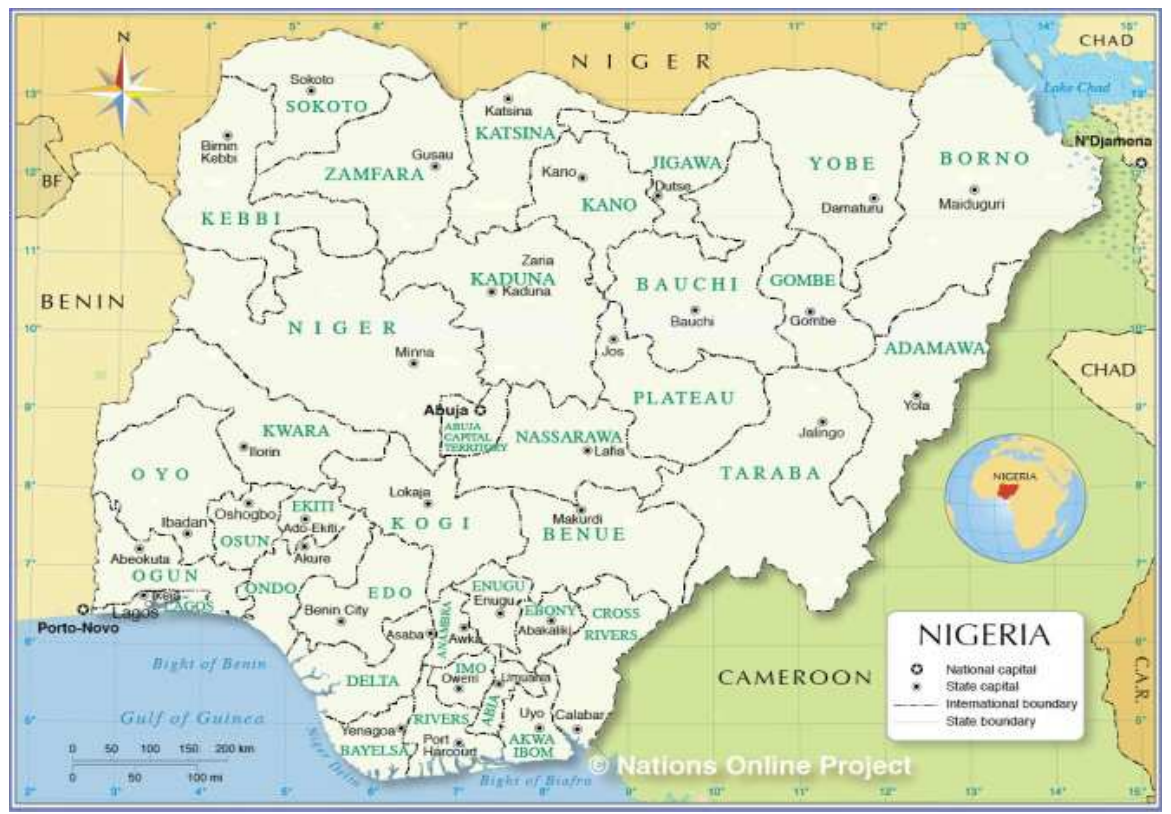

Figure 6. The Study Area Map of Nigeria. 


\section{Material and Methods}

The responses of the farmers in different locations of the four local government areas can be seen from the decision table as below:

Table 1. The Decision Table.

\begin{tabular}{lll}
\hline Sub & Above 80\% & Below 20\% \\
\hline The potential importance of maize, in Nigeria. & $\mathrm{X}$ & $\mathrm{X}$ \\
I do not know & & $\mathrm{X}$ \\
State open questionnaires & & \\
\hline
\end{tabular}

The below are the points ticked by the majority of the people (above $80 \%$ table 1) from the questionnaires who understood and supported, the usefulness of maize before harvest and storage in Nigeria:

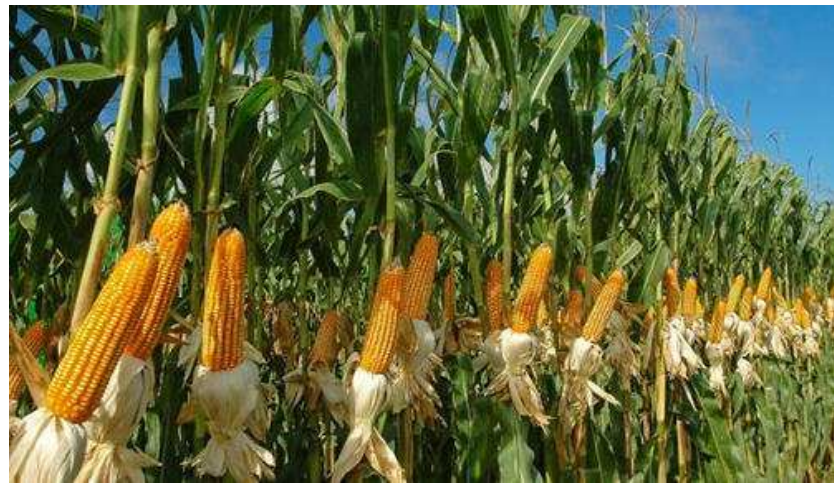

Figure 7. Maize (Zea Mays L), Importance.

[a]. Maize may prevent diabetes and hypertension. [b]. Maize has anti-cancer properties. [c]. It is the most productive grain crops in the middle and northern belts of Nigeria where sunshine is adaptable and rainfall is moderate. [d]. The crop is richer in vitamins A, and E, carbohydrates, essential minerals, and contain $9 \%$ protein. [e]. In all parts of Africa, green (fresh) maize is boiled or roasted in its cob and served as snacks. [f]. Maize helps in preventing skin problems. [g]. Maize is often consumed as vegetable. [h]. It serves as a basic raw materials to thousands of industrial products that may includes: alcoholic, beverages, pharmaceutical, food sweeteners, food cereals, cosmetic and films, gums, package, textile, paper industries and so on. [i]. Maize helps in improving vision. [j]. As one of African's dominant food crops, maize can be consumed in varied forms, such as: maize flour for confectionaries, semo (for swallow with soup), as corn beef, mill (for animals feeding), as roaster corn, it can be boiled or prepared as porridge. [k]. Maize is good for health digestion due to fibber content. [1]. Maize helps in lowering LDB (bad) cholesterol. [m]. In Nigeria, more than $60 \%$ of maize production is also consumed by industrial sector for the production of beer, malt drinks, maize flakes, starch, syrup, dextrose, and animal feed, because there is so much value in the industrial processing of maize, especially into animal feed. [n]. Maize is beneficial for the heart. [o]. In tropical and sub tropical countries, a large proportion of the grain, (such as maize) is harvested and stored under hot and humid conditions, and most farmers lack proper knowledge, equipment methods of drying grains. [p]. Insect pests can seriously reduce plant implantation, plant population, plant growth and subsequent yield potential, and must be monitored prior to planting. [q]. Birds are always problems to maize. They eat newly sealed seeds and destroy the entire root. To control them, design a rough cloth on dry trees, like a stature of human being in all conspicuous areas inside the farm. (as wind blows, since they are birds, they ran away and never turn back). [r]. Black earwigs is a sporadic and potentially important pest of maize. Black earwigs eat newly sealed seed and the roots of crops resulting in a poor establishment. [s]. Maize is rich in dietary $\mathrm{D}$ and calories which are a good source of energy.

\section{Results and Discussion}

Questionnaires were distributed to 4 Local government areas that is, (Ife East, Ife South, Ife Central and Ife North). The results from the questionnaires however revealed, the potential importance of maize, in Nigeria, are manifold:

There was a significant difference on the people in all the local government areas visited, $(p>0.01)$, and $(p>0.05)$ respectively.

Table 2. People's respondent.

\begin{tabular}{|c|c|c|c|c|c|c|c|c|}
\hline & Ife East & & Ife South & & Ife Central & & Ife North & \\
\hline Wards & $\begin{array}{l}\text { The potential } \\
\text { importance of } \\
\text { maize, in Nigeria }\end{array}$ & $\begin{array}{l}\text { I do not } \\
\text { know }\end{array}$ & $\begin{array}{l}\text { The potential } \\
\text { importance of } \\
\text { maize, in Nigeria }\end{array}$ & $\begin{array}{l}\text { I do not } \\
\text { know }\end{array}$ & $\begin{array}{l}\text { The potential } \\
\text { importance of } \\
\text { maize, in Nigeria }\end{array}$ & $\begin{array}{l}\text { I do not } \\
\text { know }\end{array}$ & $\begin{array}{l}\text { The potential } \\
\text { importance of } \\
\text { maize, in Nigeria }\end{array}$ & $\begin{array}{l}\text { I do not } \\
\text { know }\end{array}$ \\
\hline $\begin{array}{l}\text { Farmer's } \\
\text { Response }\end{array}$ & $502,71.7 \%$ & $\begin{array}{l}198, \\
28.3 \%\end{array}$ & $506,72.3 \%$ & $\begin{array}{l}194 \\
27.7 \%\end{array}$ & $493,70.4 \%$ & $\begin{array}{l}207, \\
29.6 \%\end{array}$ & $492,70.3 \%$ & $\begin{array}{l}208 \\
29.7 \%\end{array}$ \\
\hline
\end{tabular}

From the above table 2, in Ife East, there are 502 people's response with $71.7 \%$, Ife South, 506 with $72.3 \%$, Ife Central, 493 with $70.4 \%$, and Ife North, 492 with $70.3 \%$, were those
Farmers who supported, the potential importance of maize, in Nigeria, while in Ife East, 198 with 28.3\%, Ife South, 194 with $27.7 \%$, Ife Central, 207 with $29.6 \%$, and Ife North, 208 with 
$29.7 \%$ respectively, could not even know whether, there is any need, for the potential importance of maize, in Nigeria, or not.

Table 3. The different locations as (A, B, C, D, E, F, and $G$,) and the local government areas as (IFE EAST, IFE SOUTH, IFECENTRAL, AND IFE NORTH respectively). And the summary data collected, from the 4 Local Governments sampled, out of which 700 were used in each local government.

\begin{tabular}{|c|c|c|c|c|c|c|c|c|c|}
\hline \multirow[t]{2}{*}{ Local government } & \multirow{2}{*}{$\begin{array}{l}\text { Location } \\
\text { A }\end{array}$} & \multicolumn{2}{|l|}{ Ife east } & \multicolumn{2}{|c|}{ Ife south } & \multicolumn{2}{|c|}{ Ife central } & \multicolumn{2}{|c|}{ Ife north } \\
\hline & & 76 & 24 & 78 & 22 & 70 & 30 & 72 & 28 \\
\hline & B & 63 & 37 & 67 & 33 & 64 & 36 & 64 & 36 \\
\hline & $\mathrm{C}$ & 71 & 29 & 68 & 32 & 75 & 25 & 68 & 32 \\
\hline & $\mathrm{D}$ & 77 & 23 & 72 & 28 & 73 & 27 & 79 & 21 \\
\hline & $\mathrm{E}$ & 76 & 24 & 70 & 30 & 68 & 32 & 67 & 33 \\
\hline & $\mathrm{F}$ & 74 & 26 & 75 & 25 & 67 & 33 & 68 & 32 \\
\hline & G & 65 & 35 & 76 & 24 & 76 & 24 & 74 & 26 \\
\hline TOTAL $=$ & 7 & 502 & 198 & 506 & 194 & 493 & 207 & 492 & 208 \\
\hline Grand Total $=$ & 7 & 700 & & 700 & & 700 & & 700 & \\
\hline
\end{tabular}

Table 4. The descriptive statistics.

/VARIABLES $=$ IFEEAST IFESOUTH IFECENTRAL IFENORTH

/PRINT $=$ TWOTAIL NOSIG

ISTATISTICS DESCRIPTIVES

/MISSING $=$ PAIRWISE.

\begin{tabular}{llll}
\hline Descriptive Statistics & & & N \\
\hline & Mean & Std. Deviation & 7 \\
\hline IFEEAST & 71.7143 & 5.64843 & 7 \\
IFESOUTH & 72.2857 & 4.19183 & 7 \\
IFECENTRAL & 70.4286 & 4.42934 & 7 \\
IFENORTH & 70.2857 & 5.05682 & \\
\hline
\end{tabular}

Correlations

Table 5. The Pearson Correlation of the 4 local governments.

\begin{tabular}{|c|c|c|c|c|c|}
\hline \multicolumn{6}{|l|}{ Correlations } \\
\hline & & IFEEAST & IFESOUTH & IFECENTRAL & IFENORTH \\
\hline \multirow{4}{*}{ IFEEAST } & Pearson Correlation & 1 & .307 & .059 & .383 \\
\hline & Sig. (2-tailed) & & .503 & .900 & .397 \\
\hline & $\mathrm{N}$ & 7 & 7 & 7 & 7 \\
\hline & Pearson Correlation & .307 & 1 & .253 & .514 \\
\hline \multirow{3}{*}{ IFESOUTH } & Sig. (2-tailed) & .503 & & .585 & .237 \\
\hline & $\mathrm{N}$ & 7 & 7 & 7 & 7 \\
\hline & Pearson Correlation & .059 & .253 & 1 & .656 \\
\hline \multirow[t]{3}{*}{ IFECENTRAL } & Sig. (2-tailed) & .900 & .585 & & .110 \\
\hline & $\mathrm{N}$ & 7 & 7 & 7 & 7 \\
\hline & Pearson Correlation & .383 & .514 & .656 & 1 \\
\hline \multirow[t]{2}{*}{ IFENORTH } & Sig. (2-tailed) & .397 & .237 & .110 & \\
\hline & $\mathrm{N}$ & 7 & 7 & 7 & 7 \\
\hline
\end{tabular}

Table 6. The Statistics, i.e., valid missing, std. Error of mean, mean, mode, median, variance, skewness, std. Deviation, sum, calculated group data, percentiles, minimum and maximum, etc., of the 4 local government areas.

FREQUENCIES VARIABLES=IFEEAST IFESOUTH IFECENTRAL IFENORTH

$/ N T I L E S=4$

/NTILES $=10$

/STATISTICS=STDDEV VARIANCE RANGE MINIMUM MAXIMUM SEMEAN MEAN MEDIAN MODE SUM SKEWNESS SESKEW

KURTOSIS SEKURT

/GROUPED =IFEEAST IFESOUTH IFECENTRAL IFENORTH

/ORDER $=$ ANALYSIS.

\begin{tabular}{|c|c|c|c|c|c|}
\hline \multicolumn{6}{|l|}{ Statistics } \\
\hline & & IFEEAST & IFESOUTH & IFECENTRAL & IFENORTH \\
\hline \multirow{2}{*}{$\mathrm{N}$} & Valid & 7 & 7 & 7 & 7 \\
\hline & Missing & 0 & 0 & 0 & 0 \\
\hline Mean & & 71.7143 & 72.2857 & 70.4286 & 70.2857 \\
\hline Std. Error of Mean & & 2.13491 & 1.58436 & 1.67413 & 1.91130 \\
\hline Median & & $74.0000^{\mathrm{a}}$ & $72.0000^{\mathrm{a}}$ & $70.0000^{\mathrm{a}}$ & $69.3333^{\mathrm{a}}$ \\
\hline Mode & & 76.00 & $67.00^{\mathrm{c}}$ & $64.00^{\mathrm{c}}$ & 68.00 \\
\hline Variance & & 31.905 & 17.571 & 19.619 & 25.571 \\
\hline
\end{tabular}




\begin{tabular}{|c|c|c|c|c|c|}
\hline \multicolumn{6}{|l|}{ Statistics } \\
\hline & & IFEEAST & IFESOUTH & IFECENTRAL & IFENORTH \\
\hline \multicolumn{2}{|l|}{ Skewness } & -.839 & .062 & -.094 & .740 \\
\hline \multicolumn{2}{|c|}{ Std. Error of Skewness } & .794 & .794 & .794 & .794 \\
\hline \multicolumn{2}{|l|}{ Kurtosis } & -1.145 & -1.688 & -1.369 & .094 \\
\hline \multicolumn{2}{|c|}{ Std. Error of Kurtosis } & 1.587 & 1.587 & 1.587 & 1.587 \\
\hline \multicolumn{2}{|l|}{ Range } & 14.00 & 11.00 & 12.00 & 15.00 \\
\hline \multicolumn{2}{|l|}{ Minimum } & 63.00 & 67.00 & 64.00 & 64.00 \\
\hline \multicolumn{2}{|l|}{ Sum } & 502.00 & 506.00 & 493.00 & 492.00 \\
\hline \multirow{9}{*}{ Percentiles } & 10 & $63.4000^{\mathrm{b}}$ & $67.2000^{\mathrm{b}}$ & $64.6000^{\mathrm{b}}$ & $64.6000^{\mathrm{b}}$ \\
\hline & 20 & 64.8000 & 67.9000 & 66.7000 & 66.7000 \\
\hline & 25 & 66.5000 & 68.5000 & 67.2500 & 67.1667 \\
\hline & 30 & 68.6000 & 69.2000 & 67.6000 & 67.4000 \\
\hline & 40 & 71.9000 & 70.6000 & 68.6000 & 67.8667 \\
\hline & 50 & 74.0000 & 72.0000 & 70.0000 & 69.3333 \\
\hline & 75 & 76.1667 & 75.7500 & 74.5000 & 73.5000 \\
\hline & 80 & 76.4000 & 76.2000 & 75.1000 & 74.5000 \\
\hline & 90 & 76.8667 & 77.6000 & 75.8000 & 78.0000 \\
\hline
\end{tabular}

a. Calculated from grouped data.

b. Percentiles are calculated from grouped data.

c. Multiple modes exist. The smallest value is shown

Frequency Table

Tables 7, 8, 9, and 10. The frequency Tables, valid and cumulative percentage for (Ife East, Ife South, Ife Central and Ife North).

Table 7. Frequency Table, valid and cumulative percentage of Ife East.

\begin{tabular}{|c|c|c|c|c|c|}
\hline \multicolumn{6}{|c|}{ IFEEAST } \\
\hline & & Frequency & Percent & Valid Percent & Cumulative Percent \\
\hline \multirow{6}{*}{ Valid } & 63.00 & 1 & 14.3 & 14.3 & 14.3 \\
\hline & 65.00 & 1 & 14.3 & 14.3 & 28.6 \\
\hline & 71.00 & 1 & 14.3 & 14.3 & 42.9 \\
\hline & 74.00 & 1 & 14.3 & 14.3 & 57.1 \\
\hline & 76.00 & 2 & 28.6 & 28.6 & 85.7 \\
\hline & 77.00 & 1 & 14.3 & 14.3 & 100.0 \\
\hline
\end{tabular}

Table 8. Frequency Table, valid and cumulative percentage of Ife South.

\begin{tabular}{|c|c|c|c|c|c|}
\hline \multicolumn{6}{|c|}{ IFESOUTH } \\
\hline & & Frequency & Percent & Valid Percent & Cumulative Percent \\
\hline \multirow{8}{*}{ Valid } & 67.00 & 1 & 14.3 & 14.3 & 14.3 \\
\hline & 68.00 & 1 & 14.3 & 14.3 & 28.6 \\
\hline & 70.00 & 1 & 14.3 & 14.3 & 42.9 \\
\hline & 72.00 & 1 & 14.3 & 14.3 & 57.1 \\
\hline & 75.00 & 1 & 14.3 & 14.3 & 71.4 \\
\hline & 76.00 & 1 & 14.3 & 14.3 & 85.7 \\
\hline & 78.00 & 1 & 14.3 & 14.3 & 100.0 \\
\hline & Total & 7 & 100.0 & 100.0 & \\
\hline
\end{tabular}

Table 9. Frequency Table, valid and cumulative percentage of Ife Central.

\begin{tabular}{|c|c|c|c|c|c|}
\hline \multicolumn{6}{|c|}{ IFECENTRAL } \\
\hline & & Frequency & Percent & Valid Percent & Cumulative Percent \\
\hline \multirow{8}{*}{ Valid } & 64.00 & 1 & 14.3 & 14.3 & 14.3 \\
\hline & 67.00 & 1 & 14.3 & 14.3 & 28.6 \\
\hline & 68.00 & 1 & 14.3 & 14.3 & 42.9 \\
\hline & 70.00 & 1 & 14.3 & 14.3 & 57.1 \\
\hline & 73.00 & 1 & 14.3 & 14.3 & 71.4 \\
\hline & 75.00 & 1 & 14.3 & 14.3 & 85.7 \\
\hline & 76.00 & 1 & 14.3 & 14.3 & 100.0 \\
\hline & Total & 7 & 100.0 & 100.0 & \\
\hline
\end{tabular}


Table 10. Frequency Table, valid and cumulative percentage of Ife North.

\begin{tabular}{|c|c|c|c|c|c|}
\hline \multicolumn{6}{|c|}{ IFENORTH } \\
\hline & & Frequency & Percent & Valid Percent & Cumulative Percent \\
\hline \multirow{7}{*}{ Valid } & 64.00 & 1 & 14.3 & 14.3 & 14.3 \\
\hline & 67.00 & 1 & 14.3 & 14.3 & 28.6 \\
\hline & 68.00 & 2 & 28.6 & 28.6 & 57.1 \\
\hline & 72.00 & 1 & 14.3 & 14.3 & 71.4 \\
\hline & 74.00 & 1 & 14.3 & 14.3 & 85.7 \\
\hline & 79.00 & 1 & 14.3 & 14.3 & 100.0 \\
\hline & Total & 7 & 100.0 & 100.0 & \\
\hline
\end{tabular}

Figures 8, 9, 10, and 11. The Bar Charts, for (Ife East, Ife South, Ife Central and Ife North). Bar Chart

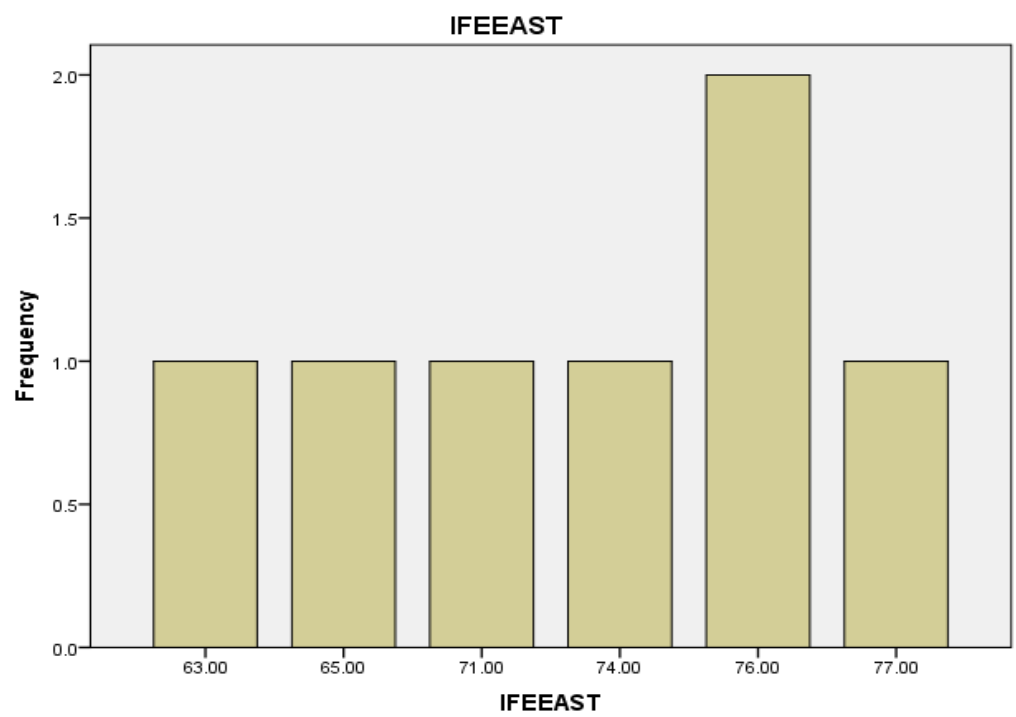

Figure 8. The Bar Chart of Ife East.

The vertical coordinates represent the frequency (that is, the rate of observations or occurrences), from the data analysis while the horizontal coordinates represent the range from the valid data in Table 7, (that is), based on 1 unit interval as:[63.00, $65.00,71.00,74.00,76.00$, and 77.00], respectively.

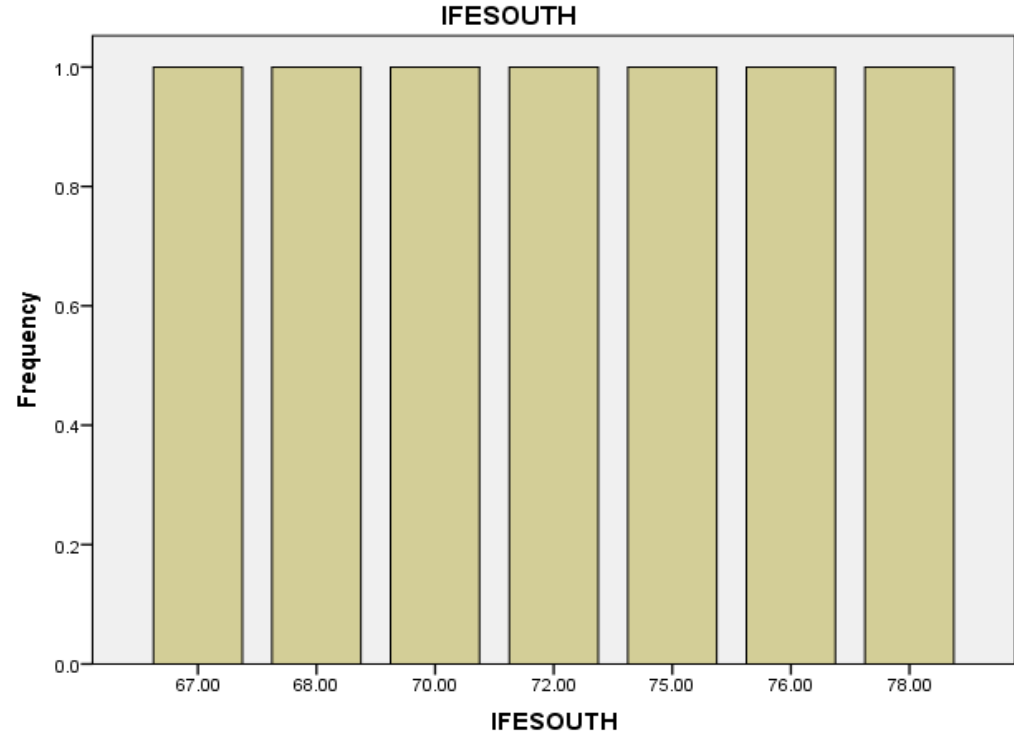

Figure 9. The Bar Chart of Ife South.

The vertical coordinates represent the frequency (that is, the rate of observations or occurrences) from the data analysis while the horizontal coordinates represent the range from the valid data in Table 8, (that is), based on 1 unit interval as:[67.00, 
$68.00,70.00,72.00,75.00,76.00$, and 78.00$]$, respectively.

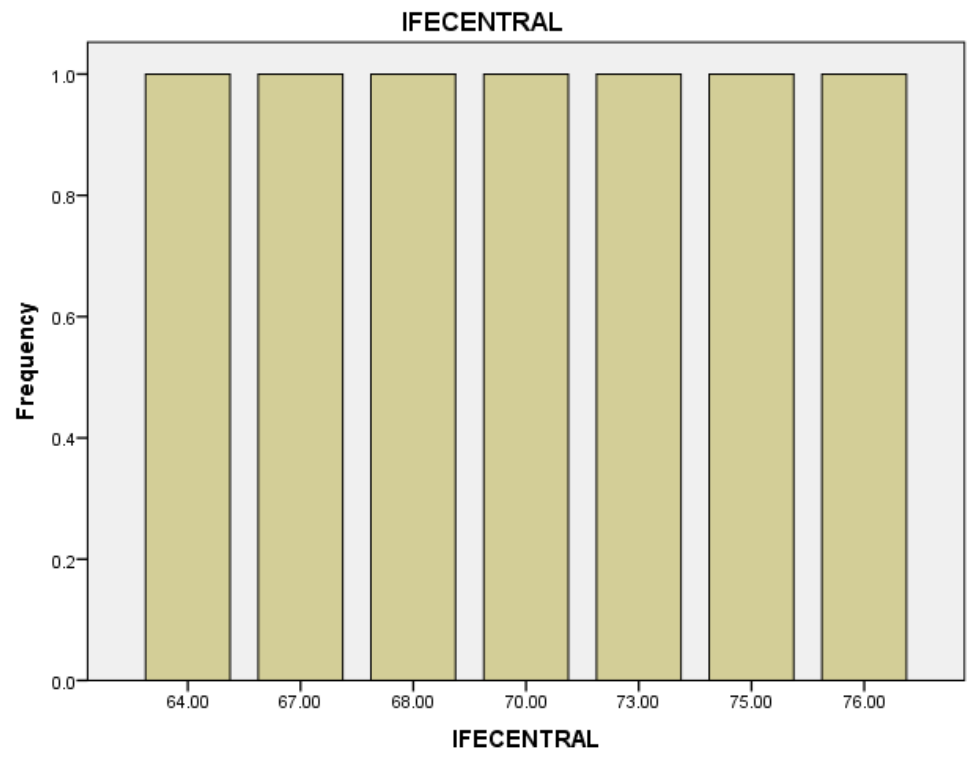

Figure 10. The Bar Chart of Ife Central.

The vertical coordinates represent the frequency (that is, the rate of observations or occurrences), from the data analysis while the horizontal coordinates represent the range from the valid data in Table 9, (that is), based on 1 unit interval as:[64.00, $67.00,68.00,70.00,73.00,75.00$, and 76.00], respectively.

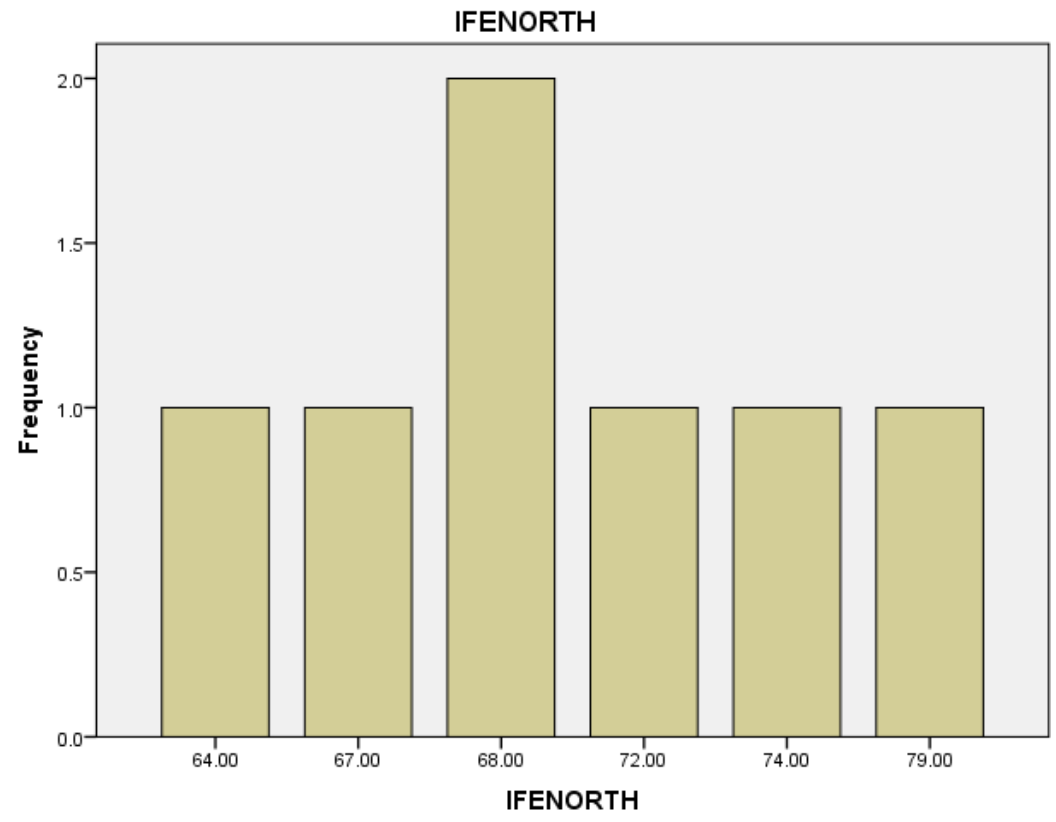

Figure 11. The Bar Chart of Ife North.

The vertical coordinates represent the frequency (that is, the rate of observations or occurrences) from the data analysis while the horizontal coordinates represent the range from the valid data in Table 10, (that is), based on 1 unit interval as:[64.00,67.00, 68.00, 72.00, 74.00 and 79.00], respectively.

\section{Recommendations}

1. Nigerian Government should encourage Agriculture, of maize plantation, both at the secondary level to higher Institution's level, since food is health, and health is wealth. 2. Adult awareness training on maize should be made possible and effective to all farmers, in all the local governments, in both the rural and urban areas of Nigeria, to make them become suitable for maize plantation, so as to reduced, maize spoilage. 3. Workshop at different intervals should be organized in Ile-Ife Kingdom, to farmers, so as to educate them in the uses of current farmer's equipments, to increase their maize output production. 4 . Some of the rural 
areas roads in Osun State, Nigeria, are bad. Government should provide good roads to farmers, to enable ease carriage of their maize crops harvest to save the cost of transportation of carriage, to urban areas. 5. Government should provide electricity in rural areas for Farmers, to enable them, stay longer in their farm for maximum increase in their maize harvest Production. 6. Government should encourage farmers by providing and bringing agricultural equipments like cutlasses, sprayers, hoes,. etc., and farm products like herbicides, fertilizers, insecticides, etc., closer to them, so as to reduce the cost of maize harvest to the buyers. 7 . Government should erect large storage at intervals for farmers in order to encourage them to keep their agricultural products to minimize frequent maize spoilage.

\section{Conclusion}

The following conclusions are made based on the findings of this study. Since maize is one of African's dominant food crops, that can be consumed in varied forms, such as: maize flour for confectionaries, semo (for swallow with soup), as corn beef, mill (for animals feeding), as roaster corn, to be boiled or prepared as porridge; also in Nigeria, more than $60 \%$ of maize production, is consumed by industrial sector for the production of beer, malt drinks, maize flakes, starch, syrup, dextrose, and animal feed, because there is so much value in the industrial processing of maize, especially into animal feed; the results of this study provide the empirical evidence that, the potential importance of maize, in Nigeria, has enhanced the farmers and people's achievement in Nigeria. The farmers and the people of Nigeria, therefore should make use of the potential importance of maize, in Nigeria, to argument their, business techniques, coupled, with decision aids, in order to attain minimum goal needed for everybody in Nigeria, and Diaspora at large.

\section{Acknowledgements}

The Author wishes to express his appreciations to all especially those whose papers that are shown in my references to provide the premise for this study, and Dr. / Chief Ramond Adedoyin, (The ATOBATELE of The "SOURCE" AND MAYE of The Yoruba Kingdom), The Chancellor and Founder of Oduduwa University for providing the fund and space to carry out this research work / study.

\section{References}

[1] Aderinlewo E. O., 1982. Basic Secondary Science Book 1. Published by Evans Brothers Limited. Montague House, Russell square London WC1B5BX. Composition in 11 on 13 point century by Film type services Limited, Scarborough, North Yorkshire and Printed by William Clowes (Beccles) Limited, Beccles and London ISBN 0237505274.NPR 1137.

[2] Ashutosh Kar, 2011. Advanced Practical Chemistry. First Edition. Printed in India at Saras Graphics, Rai, Haryana. Typeset at Goswami Associates, Delhi. Publishing for one world. New Age International (P) Limited, Publishers. 4835/24, Ansari Road, Daryaganj, NewDelhi-110002. ISBN (0): 81-224-1539-9. ISBN (13): 978-81-224-1539-1

[3] Dr. Tilak Ram, 2013. Food Chemistry. Published in India by Random Publications.4376-A/4B. Gall Murari Lai, Ansari Road, New Delhi-110002. Typesetting by: Friends Media, Delhi-110087. Digitally Printed at: Replica Press Pvt. Ltd. ISBN 978-93-5111-032-3.

[4] Elservier, E. 2009. Guide to Protein Purification. $2^{\text {nd }}$ Edition. Academic Press. 525B street, suite 1900. San Diego, a 921014495, USA, 30 corporate Drive. Suite 400, Burlington, MA 01803, USA.32 Jamestown Road, London. NW1 7BY, UK. ISBN: 978-0-12-374536-1 (hardback). ISBN: 978-0-12374978-9 (paper back). ISSN: 0076-6879.

[5] Erelu, O. O., 2008. Cocoa for Health and Wealth. A Paper presented in a Fourth Cocoa Day Celebration in Osun State between $22^{\text {nd }}-24^{\text {th }}$ April.

[6] Fan Y. Ding Z. Yang L. et al. A Preliminary Study on Bioactivity of Orange and Tangerine Peal extracts against Apluis and mites. Zhongguo Zhong Yao Za Zhi 1995 Jul: 20 (7): 397-8,446. 1995. PMID: 13090.

[7] George Coulouris, Jean Dollimore and Tim Kindberg, 2011. Distributed Systems, Concepts and Design, $4^{\text {th }}$ Edition. Published by Dorling Kindersley [India] Pvt. Ltd. Licensees of Pearson Education in South Asia. Head Office: $7^{\text {th }}$ floor, Knowledge Bouleward. A-8[A], Sector-62.Noida-201309, U.P India Registered Office: 11 Community Centre, Panchs heel Park. New Delhi110017, India. Printed in India by Manipal Press Ltd. ISBN978-81-317-1840-7. Authorized adaptation from the United Kingdom Edition, Entitled Distributed System Concepts and Design. Forth Edition, ISBN: 9780321263544 by Coulouris, George: Dollimore, Jean; Kindberg, Tim; Published by Education, Ltd. Copyright @ 2005. Indian Subcontinent Adaptation copyright@ 2009 Dorling Kindersley [India] Pvt. Ltd.

[8] Gordon M. Ward law, 2003. Contemporary Nutrition Issues and Insight. Fifth Edition. Published by McGraw-hill, a business unit of McGraw-Hill Companies, Inc., 122 1avenue of the Americas, New York, NY 10020. ISBN: 0-07-286530X. ISBN: 0-07-119903-X(15E). International Edition. ISBN: 0-07-118808-X.

[9] Honow R., Laube N. Schneider A, Kessier T. Hesser. Influence of grape fruit, Orange, and apple juice consumption on urinary variables and risk of crystallization. Br. Intr. Aug: 90 (2) 295-300.2003. PMID: 12908889.

[10] Jill Norman, 1997. The Classic Herb Cook Book. First published in Great Britain by Dorling Kindersley Limited. 9, Henrietta Street, London WC2E8PS. Reprint in 1997. A CIP fort his book is available from the British Library. ISBN: 0751303232. Reproduced in Italy by Scanner Service SRL. Printed and bound in Italy by a Monadori, Veronica.

[11] John R. Holum, 1975. Experiments in General Organic and Biological Chemistry. A laboratory Manual, Forth Edition. New York. London. Sydney. Toronto. Printed in the United State of America. 10987654321.

[12] Kumar R., 1984. InsectPest Control. First Published in Great Britain. Printed and bound in Great Britain by Athenaeum Press Ltd. Gates head British Library Cataloguing in Publication Data. ISBN 0713180838. Member of the Holder Headline Group. 338 Euston Road, London WW1 3BH. 
[13] Melvin Calvin and J. A Bassham1962. The Photosynthesis of Carbon Compounds. Library of Congress Catalogue Card Number: 62-10567. Manufactured in the United States of America. The Manuscripts was received November 15, 1961, and Published February 27, 1962. W. A. Benjamin, Inc. 2465 Broadway, New York 25, New York.

[14] Nyle C. Brandy, 1990. The nature and Properties of Soils. Printed in the United State of America by Mac Millian Publishing Company. Simon \& Schuster A. Viacon Company, Upper Saddle River, New Jersey, 074p58. ISBN 0-13-852444-0.

[15] Oluyole K. A., 2005. Evaluation of the Economic of Post Harvest Processing of Cocoa in Cross River State, Nigeria. Journal of Agriculture, Forestry and the Social Sciences.

[16] O. P. Agarwal, 2014. Organic Chemistry, Natural Products Volume-1. Published by: Satyendra Rostogi, "mitra" for KRISHNA Prakasha media (P) Ltd.11, Shivaji Road, Meerut25001 (U.P.) India. Printed at Majmoon Press, Meerut. Typing: DEBUG CC. (The computer concern) Ghazia bad, ISBN: 97881-8283-556-6.
[17] Rai H., 2004. Basic Industrial Biochemistry. Printed in India at Ram print graph, Delhi. Typeset at In-house. Publishing for one world. New Age International (P) limited. Publishers. 4835/24, Ansari Road, Daryaganj, NewDelhi-110002. ISBN: 978-81-224-3404-0. 295.C-12-04-6261.

[18] Rapisarda P. Tomaino A. Lo Casco R., et al. Antioxidant effectiveness as influenced by Phenolic content of fresh orange juices. J, Agric Food Chem. 1999 Nov: 47 (11): 471823-.1999.PMID: 13080.

[19] S. K. Jain, 2001. Mineral Processing. For CBS Publishers and Distributors Pvt. Ltd. CBS Plaza, 4819/XI Prah lad Street, 24 Ansari Road, Daryaganj, New Delhi-110002, India. Ph: 23289259, 232668861, 23266867. ISBN: 81-239-0753-2.

[20] Tilak Wasan, 2015. Solid Waste Pollution and Health. Published at Arisari Road, 4383/4B, Darga Ganj. New Delhi110002 (India). ISBN: 978-93-5056-306-9. Discovery Publishing House PVT. Ltd. Printed at: Infinity Imaging Systems Delhi. 